\title{
Erratum: Biotech's wellspring: the health of private biotech in 2013
}

Brady Huggett

Nat. Biotechnol. 32, 428-435 (2014); published online 7 May 2014; corrected after print 14 May 2014

In the version of this article initially published, in Box 3, it was reported that "Catabasis will instead monitor the situation as it approaches phase 3, when large amounts of capital will be required...." The line should have read, "Catabasis instead is keeping with its plan to develop the phase 2 package for its lead program and timing a public financing with phase 3 trials...." Michael Jirousek was also incorrectly identified as founder and CEO. He is the company's co-founder and CSO.

On p. 431, column 2, Adam Cutler was incorrectly quoted as saying, “...but today, anyone 'deemed to have an exciting enough technology platform with big enough names involved, either in management or on the board or as scientific founders-that's enough to get people excited"' It should have read, "...but in 2013 and the beginning of 2014, anyone 'deemed to have an exciting enough technology platform with big enough names involved, either in management or on the board or as scientific founders—-that was enough to get people excited"'

\section{Erratum: The anatomy of successful computational biology software}

Stephen Altschul, Barry Demchak, Richard Durbin, Robert Gentleman, Martin Krzywinski, Heng Li, Anton Nekrutenko, James Robinson, Wayne Rasband, James Taylor \& Cole Trapnell

Nat. Biotechnol. 31, 894-897 (2013); published online 8 October 2013; corrected after print 9 May 2014

In the version of this article initially published, in Table 1, Steven Salzberg should have been listed as the second, and not the last, of the creators of the Cufflinks software. The error has been corrected in the HTML and PDF versions of the article.

\section{Corrigendum: Combinatorial discovery of polymers resistant to bacterial attachment}

Andrew L Hook, Chien-Yi Chang, Jing Yang, Jeni Luckett, Alan Cockayne, Steve Atkinson, Ying Mei, Roger Bayston, Derek J Irvine, Robert Langer, Daniel G Anderson, Paul Williams, Martyn C Davies \& Morgan R Alexander Nat. Biotechnol. 30, 868-875 (2012); published online 12 August 2012; corrected after print 9 May 2014

In the version of this article initially published, the label of the 6th sample across in Figure 5 should have read 4(100\%), not B(100\%). The error has been corrected in the HTML and PDF versions of the article.

\section{Erratum: Is this really the RNAissance?}

Editorial

Nat. Biotechnol. 32, 201 (2014); published online 10 March 2014; doi:10.1038/nbt.2853; corrected after print 9 May 2014.

In the version of this article initially published, Alnylam Pharmaceuticals was misspelled. The error has been corrected in the HTML and PDF versions of the article.

\section{Corrigendum: Rational drug repositioning by medical genetics}

\section{Zhong-Yi Wang \& Hong-Yu Zhang}

Nat. Biotechnol. 31, 1080-1082 (2013); published online 6 December 2013; corrected after print 9 April 2014

In the version of this article initially published, the corresponding author was given in the HTML as Z.-Y. Wang, rather than the H.-Y. Zhang. The error has been corrected in the HTML version of the article. 